I would like to thank Dr. John Marshall not only for being the subject for the experiments, but also for his stimulating discussions, and I would also like to thank Dr. E. Arnold Carmichael for his interest and constructive criticism.

\section{REFERENCES}

Addis, H. St. C. C., Jepson, R. P., and Kellgren, J. H. (1950). Clin. Sci., 9, 271.
Armstrong, D., Dry, R. M. L., Keele, C. A., and Markham, J. W. (1951). J. Physiol., Lond., 115, 59 P.

Bishop, G. H. (1944). J. Neurophysiol., 7, 71.

Heinbecker, P. (1929). Amer. J. Physiol., 89, 58.

Kugelberg, E. (1944). Acta

$\longrightarrow$ (1946) Brain, 69, 310 . Macmillan, New York.

Lewis, T. (1942). Pain. Macmillan, New York.

Merrington, W. R., and Nathan, P. W. (1949). Neurosurgery and Psychiatry, 12, 1.

Thompson, I. M., and Kimball, H. S. (1936). Proc. Soc. exp. Biol., N.Y., 34, 601.

Thörner, W. (1924). Pfiügers Arch ges. Physiol., 204, 747.

\title{
Foundations' Fund for Research in Psychiatry
}

The Social Research Foundation has made a grant of approximately six million dollars for psychiatric research to Yale University and requested the Corporation of Yale University to establish the Foundations' Fund for Research in Psychiatry. The purpose of this new foundation is, in the words of the donor, " to support research into why people become mentally and emotionally ill, why they get well, how best to help them get well and how best to help them from becoming mentally and emotionally ill."'

The distribution of this fund will not be confined to Yale University. Present plans contemplate that both income and principal will be expended in accordance with the stated purpose over a period of about 20 years.
At its initial meeting held in New Haven on March 27 and 28, the Board of Directors discussed organization and general policy questions. It expressed interest in the training and support of competent investigators, in the development of appropriate research methods, in encouraging the pursuit of significant problems, and in the advancement of the basic behavioral and biological sciences as related to psychiatry.

The Board invites the communication of ideas from interested sources but will not be ready to make decisions on grants for at least six months (from April, 1953).

The temporary address of the new organization is 333 Cedar Street, New Haven 11, Connecticut, U.S.A.

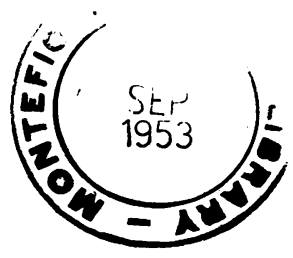

